\title{
Law and Corruption in Albania and in the South-Eastern European Countries: A Comparative Analysis
}

\author{
Ph.D. Dr. Rezarta Tahiraj \\ University "Aleksandër Xhuvani" Elbasan - Albania \\ E-mail: rtahiraj.uniel@gmail.com
}

\section{Doi:10.5901/mjss.2014.v5n7p136}

\section{Abstract}

The corruption is a phenomenon highly detrimental to the stability of democratic institutions because it undermines considerably the climate of business discouraging private investment and hampering economic growth. Whereby, the Stabilization process in SEE goes in hand with fight against the corruption; accordingly, none of the country of the SEE can afford the social, political and economic costs that entail the bribery and corruption. As such, the fight or control against the corruption has moved to the top of regional political agenda ranking prominently among technical assistance activities at the international level as appears to be the Stability Pact Anti-Corruption Initiative adopted for the countries of the SEE. In relation to the case of Albania, the control of corruption appears to be still highly problematic due to fact that comprises a wide range of human activities which are criminalized. Instead of asking what is wrong in law which has traditionally been the focus of analysis, the proposed paper has as target to identify the reasons for which the law tries to change the behaviour of private and public persons which fail to act as expected. and the implementation of the Stability Pact Anti-Corruption Initiative in comparison with others countries of SEE as Macedonia and Croatia; an analysis which the target is to evidence if the legal and institutional framework of Albania and others countries of SEE is mostly in line with the European standards and practice.

Keywords: Albania, South-Eastern European (SEE) Countries, Stability Anti-Corruption Pact.

\section{From the Genesis to the Modern Albanian Criminal Law on Corruption}

The genesis and development of criminal law provisions on corruption in Albania is outlined along the historical ages of the establishment, consolidation and improvement of the Albanian State as well as of its legal order.

To rebuild the Albanian legal tradition in the field of criminal law on corruption, it is important to dwell on the establishment process of the criminal law as well as the substantial reforms applied in the past periods.

The first impressions of corruption we find in Illyrian provinces around the V-the century before Christ while, from legal point of view, the corruption becomes known with the Statues of Shkodra in the beginning of the years 1346 when the popular customary laws still does not recognize the corruption as a crime.

The occupation of Albania from the Ottoman Empire in the 1478 generates the influence of the Ottoman legislation in Albania whose effects are also produced in the popular customary laws. Accordingly, the corruption in Albania until the proclamation of the independence in the 1912 operates mainly to the direction of the Ottoman invaders.

The legislation on corruption undergoes new developments in the years 1928-1939 of the Republic and Monarchy Age, but after the Second World War up over the years 1970 it is strictly controlled for the interests of Albanian dictatorial State to take after a new development as result of political and economic weakness of the State.

With the establishment of the new democratic State in the year 1991, the corruption, initially, undergoes a new development related to a series of objective and subjective factors occurred in the period of the transition.

Afterwards, the establishment of political and economic stability produces the effectiveness of central and local government, particularly, in the field of the transparency and documentation, simplifying administrative structures and procedures as well as increased control in the context of economic growth. As result, the Albanian criminal law on corruption has the characteristics of a modern contemporary law that guarantees the fight against the corruption as identified in other legal orders which had a strong legal tradition in the field of criminal law on corruption.

\subsection{In the search of a legal notion for the phenomenon of corruption in the Age of the Old Order.}

The history of Albania, a country in SEE defined as a Region of the Western Balkans, began over two millennia ago with 
Illyrians tribes that populating its territory ${ }^{1}$.

The historical sources confirm that the corruption of officials in Illyrian provinces was born around the V-the century before Christ with the population of coastal regions and antique colonial States. In fact, the presence of corruption in Illyrians provinces is related with different forms of the organization of the State such as: 1 . the form City - State; 2 . the form of territorial Slavery which owning the State; 3 . the form of independent tribal communities. Under the first form, that of the City - State, an organization implemented according to the Greek and Roman models where was recognized the slavery we found, with the beginning and development of the State administration, a standard field of the corruption. While, under the second form that of territorial Slavery which owning the State, an organization where it was recognized the traditional economic life continued, found beginning and development the sources of incomes from the piracy when from the governor aspect was recognized only the military bureaucracy which had no reason and need to corruptive revenues given the principle of separation of spoils of war or piracy. Whereas, under the third form, that of independent tribal communities, an organization where existed the natural economy, missing the slavery and economic regime of trade as well as the administrative bureaucracy because there was only the legislative State apparatus. In this form of the organization of the State, the role of executive power was directly performed by the Assembly whilst the administration and direction of the society was not realized by the persons with the office status of clerk and the persons were not paid. In this last form of the State organization, it is important to highlight the presence of the chain of self-government of justice noted as "Presbytery" due to the recognition at the popular customary law of the reward of "benefit of job by the parties in conflict"2, confirming the inexistence of the economic and social base of corruption.

At this point, it should be emphasized that the Illyrians provinces were found with a composite legal tradition which reflects the influences of Roman cultural model ${ }^{3}$ and that of popular customary laws or Kanun - the code of honour, hospitality and blood revenge such as the Kanun of Lek Dukagjini and Kanun of Labërisë4. The Kanun includes not only a peculiar way to adjust a certain "law of retaliation", but it is an oral legal formulation, written since 1933, which is to regulate many aspects of daily life agro-pastoral and since its division in chapters, it is a mirror for the rural, patriarchal and traditional society to which the Roman Empire with its laws was foreign ${ }^{5}$. In relation to the negative phenomenon of corruption, the Kanun, concretely, the Kanun of Lek Dukagjini and Kanun of Labërisë confirm the inexistence of the articles related to the interdiction of corruption as well as its definition as a crime. Also, the content of these popular customary laws do not detect even the presence of the term "gift".

The term "corruption" becomes known for the first time in Albanian legal order in the beginning of the years 1346 with the Statues of Shkodra which the organization was made possibile according to the European City - State models ${ }^{6}$. These legal acts show the presence of special articles in the field of the prevention of corruption and its conviction in the courts and judicial officer. Concretely, the article 156 of the Statues of Shkodra states "if a judge takes the money for a trial and if this fact is proved he is obligated to pay the fines 8 hyperpere half divided with Earl and Communes and also

\footnotetext{
${ }^{1}$ About the genesis of Albanian people: (Adamiti, Le Pélasges et leurs descendants les Albanais, Caire 1903; Stipcevic A., Çdo tregim për Ballkanin fillon me llirët, Prishtinë 1985; Cuaz M., Il tema dell'identità nazionale nella storiografia albanese, Passato e Presente, Vol. 14/39, Firenze 1996; A.A. V.V., Historia e Shtetit dhe e së Drejtës në Shqipëri, Vol. 1, Tirana 2000; Swander-Sievers S. \& Fisher B. J., Albanian identities: myth and history, Bloomington 2002; Castellan G., Histoire de l'Albanie et des Albanais, Lecce 2004).

${ }^{2}$ For more see: (Hasluck M., The unwritten law in Albania, Cambridge 1954; Gjeçov P. S. C.,, Codice di Lek Dukagjini, Reale Accademia d'Italia - XX, Roma 1941; Resta P., II Kanun di Lek Dukagjini. Le basi giuridiche e morali della società albanese, Nardò 2000).

${ }^{3}$ The lands comprising modern-day Albania were occupied by the Romans in $165 \mathrm{BC}$ and incorporated into the empire for almost six centuries. Illyrian society underwent great change under Roman rule, especially, in its outward material aspect (MOMMSEN T., Römische Geschichte, trad. it., Storia di Roma antica, III, Firenze 1972, p. 680-684).

${ }^{4}$ The Kanun of Lek Dukagjini and the Kanun of Labërisë are the most important Albanian customary laws among many codes created in mountain areas of Albania over the centuries. For centuries it strictly governed social behavior and everyday life among Albanians in different historical periods.

${ }^{5}$ For more see: (Hasluck M., op. cit., Cambridge 1954; Gjeçov P. S. C., op. cit., Roma 1941; Resta P., op. cit., Nardò 2000; Tachella P., Temi e questioni di storia economica dell'Albania dalla dominazione ottomana al crollo del comunismo. Una rassegna bibliografica, Storia Economica 9/1, Napoli 2006, p. 8-9).

${ }^{6}$ The Statutes of Shkodra are a true monument of medieval Albania having the advantage of being the oldest piece of legislation produced in the territory of Albania. The text was prepared by the Legal Venice in collaboration with the authorities in the City - State of Shkodra representing the best and most vivid evidence of the close scientific collaboration between the Albanian and Italian lands as result of the strong influence of Italian culture in Albania already in the Middle Ages. The Statutes of Shkodra contains mostly criminal provisions: in fact, it is covered in both institutions the general part of criminal law that the individual offenses (Corpus Statutario delle Venezie - Statuti di Scutari - della prima metà del secolo XV con le addizioni fino al 1469, Roma 2002).
} 
the damages for those who has lost the trial; as result, the judge losses forever the right to exercise his profession in the municipality". Also, the article 276 of the Statues of Shkodra, although indirectly, interdicts the corruption of prosecutors.

Afterwards, the term "corruption" becomes also known, despite its late introduction, in the popular customary laws and concretely in the Kanun of Lek Dukagjini and Kanun of Labërisë given the influence of the Ottoman legislation after the occupation of Albania by the Ottoman Empire 7 . For the first time, the term "corruption" is defined, from the legal criminal point of view, as an interdiction act and it is configured as an isolated phenomenon with sporadic demonstration. The isolation characteristic of the corruption it is related only with the activity of the elderly members who judged with partiality and for which was condemned with "black face" or "dishonor" and not called again in judging of issues.

In the period of the Ottoman domination, the phenomenon of corruption in Albania was present in the forms of "public corruption" and "private corruption". The "public corruption" was present only in the areas where the Ottoman occupation was extended for the fact that its cultivation was made possible by the administration of the invaders in the relationships with the population. Meanwhile, the "private corruption", configured in the passive corruptive acts of major land owners with the inhabitants of the territory of their properties and as well as in the active corruptive act of private subjects for realizing the protection of economic activity, was present in paying cash, in nature or in value, bribery etc.

In relation to the legal base, it should be noted that, with the predomination of Ottoman legal system in Albania, the phenomenon of corruption in the form of bribery was disciplined by the Ottoman Penal Code of 1877 since the Islamic law noted as "Sharia" $\mathrm{did}$ non support the phenomenon of corruption in principle, although among the main principles of "Sharia" where is talked for the rights of the others is established that "Sharia" has strictly forbidden even the graft.

The Ottoman Penal Code establishes the penal acts for the phenomenon of corruption entitled "Mita" in its third part in the articles 67-81. Concretely, the article 67 defines the figure of penal act, the article 68 establishes the punishment of bribe taker, the article 69 describes the punishment and return of the given sum of bribe from the great bribe, the article 77 establishes the punishment even for the person who does not denounce the bribe, the article 78 defines the punishment for the bribe for the legal act, the article 79 treats the question of the exemption from the responsibility of bribe taker who denounce the proposal or reward given within two months, the article 80 describes the case of the thief when an officer person makes payments less than reflected and the article 81 that establishes the responsibility of giving reward to a person with the aim of committing a penal act by punishing the intermediary person for that act and not for bribe.

However, it should be emphasized that the prevision of these articles did not punished the phenomenon of corruption for twos reasons: 1 . the absence of the efficiency of Ottoman administration under the jurisdiction of which was the control of real situation in execution of the laws; 2 . the influence of major owners who were not interested in such a thing. For these reasons the corruption took large dimensions in various form in the cities and produced social contradictions that become very problematic for the Ottoman State and, as result, it was passed in extreme measurements as the punishment with death ${ }^{9}$.

The proclamation of the independence of Albania in the 28 November 1912 did not produce any change in relation to the penal legal system in force during the predomination of the Ottoman Empire. Inheritance of the Ottoman Penal Code, it continues to assume the same structure also in relation to the penal acts related to the phenomenon of corruption. However, the lack of stability of new Albanian State and the international complicated situation generated the continuation of the corruption as well as the presence of the new forms of corruption in the Albanian administration. Regardless the preventive measures as the simplification of the administration and the fight against the bureaucracy applied in the year $1924^{10}$, the situation remained invariable from the point of view of the reformation of the Penal Code related to the penal acts of corruption and elimination or reduction of this negative phenomenon for the new Albanian State.

\footnotetext{
7 The centuries between the ends of the political independence of Albania, which occurred in 1478, to its reestablishment in 1912, mark a clear hegemony of the Ottoman cultural model: (Tahiraj R. \& Porro S., II sistema tributario in Albania. Evoluzione storica dal 1839 al 1945, Italy 2008).

8 Losano M. G., L'ammodernamento giuridico della Turchia (1839 - 1926), Milano 1990.

${ }^{9}$ This extreme measure is applied for the thirst time in the year 1770 in Pashallek of Shkodra where was condemned with death Khareman Pashe Begolli of Peja, in between the others for financial abuse too.

${ }^{10}$ Law Decree of 22 July 1924, For the proposal of Ministry of Finances that decree the forming of Commission for simplifying of bureaucracy and reduction of employers.
} 


\subsection{The metamorphosis of the legislation on corruption in the Age of the New Order.}

The years from 1925 to 1939 represent a new epoch for Albanian State and its legal order ${ }^{11}$. In conformity with Italian and French legal systems, the administrative reforms subdivide the territory of Albania in prefectures and sub prefectures. Meanwhile, the gradual abrogation of the Ottoman legislation and that of the custom laws produced the establishment of a new legal order ${ }^{12}$.

Whereby, in the year 1928 was approved the new Albanian Criminal Code which substituted the Criminal Code of Ottoman Empire of the year 1878. In fact, to the preparation of the Albanian Criminal Code of the year 1928 plaid a fundamental role the Italian doctrine of the years 1920 and obviously took as a model the Italian Penal Code of 1889 better known as "Code of Zanardelli".

It is a body of law that consecrated cornerstone principles developed by the Italian classical school such as "nullum crime, no punishment without law", "nullum crimen sine culpa." It can not show up, also, that the principles and institutions of both the general part of criminal law that the rules of the special part are almost identical to those given by the Italian Criminal Code of 1889. Thus, for example, the special part of criminal offences was divided into crimes and misdemeanours, as well as their content is prescriptive in terms of sanctions that were identical to the provisions of the Italian text.

One thing is certain: the entry into force of the Criminal Code of 1928 in Albania has been of great importance and that not only in the fight against crime, but also for having introduced a new concept on the positive law, abolishing the criminal rules that customary rules of Kanun of Leke Dukagjini and Kanun of Labërisë transmitted from the past. From this point of view, the Italian Penal Code, based on liberal principles, served as a reference point for illuminating the Albanian criminal law and the construction of criminal justice in Albania.

Regarding the phenomenon of corruption, it should be noted that the Penal Code of 1928 represents the first legal regulation in Albanian penal legislation for the problems related to the corruption. Particularly, the special part of this Code was dedicated the crimes where was talked for the bribe and for the abuse of authority, abuse of clerics in exercise of their functions, administration of justice and other respective abuses.

With the assumption of the crown of the Kingdom of Albania from the House of Savoy in 7 April $1939{ }^{13}$, in personal union with the Kingdom of Italy, did not end the era of Penal Code of 1928. It remained as the main source of criminal law and continued to assume the same structure in

relation to the penal acts related to the corruption, nevertheless was joined by a number of complementary laws enacted in responsibility order to protect the power of the new Princely House and the Duce. It is natural that such rules, by the dogmatic point of view-regulatory, had the characteristics of an exceptional, extraordinary and war criminal, characteristics attributable to military criminal law of the war, which is often willingly flew into the rules strongly influenced by undemocratic characteristics.

The tendency was also confirmed in the period just after the Italian occupation with the entry into force of the most important of the various sources of law of that historical moment or the Criminal Code of military peace time and the Military Penal Code of War, which replaced the Code of Military Justice of 1932.

During the Second World War, in the liberated territories of Albania and under the control of the organs of the People's Liberation Power, born elements of the new criminal law which the origins become by the written documents noted as "the resolutions" issued during the so-called Congress for the Liberation of Albania. The installation in Albania of the Democratic government and the entire liberation of the Albanian territory were the first steeps toward the constitution of the new political, institutional and legal order of Albanian State after the Second World War ${ }^{14}$.

\footnotetext{
${ }^{11}$ From 21.1.1925 Albania is a Republic, but in 1.9.1928 Albania become a hereditary-democratic-parliamentary monarchy having in the head the ex President of Republic Zogu that declared himself King of Albania (Biagini A., op. cit., p. 121-123; A.A.V.V. op. cit., p. 118129. Tomes J., The Throne of Zog, History Today, Tirana 2001; Tomes J. King Zog of Albania: Europe's self made Muslim monarch, New York 2004).

12 Ismet E., Zhvillimi historik i legjislacionit penal në Shqipëri, Tirana, 1997, p. 15-18.

${ }^{13}$ Gianini A., op. cit., p. 187-189; Salvatorelli L. - Mila G., Storia d'Italia nel periodo fascista, Torino, 1964, p. 1005-1007; Ballvora SH., Vendosja e rregjimit kolonial fashist të pushtimit në Shqipëri, Studime Historike N. 3, Tirana 1967; Felice De R., Mussolini il Duce. Lo Stato totalitario 1936-1940, Torino, 1981, p. 500-507; Fischer B., Albania at the war, 1939-1945, London 1999; Ciano G., Ditari i Kontit Ciano: Shqipëria (1937-1943), Tirana 1994.

${ }^{14}$ In 11.1.1945, the National Assembly abrogates de iure the Zogu Monarchy and proclaims the Popular Republic of Albania. The political and institutional model is that of Popular Democracies bases at the planned economy accordino to the model of Soviet Union. The Albanian Constitution confirms the principle of the equality, the religion liberty, the rights of the work, health and instruction. The safeguard of independence and national integrity is a constitutional principle defines as a supreme obligation and high honour for every
} 
Consequently, the Albanian State started also, although gradually, the process of radical renewal of the criminal law that resulted with the adoption of a new Criminal Code in the year 1948 which in the early years after the Second World War was preceded by a series of penal laws ${ }^{15}$.

In this manner, it is arrived at the elaboration of these legal texts that completed the contents of the new Criminal Code which entered into force in the 1 September $1952^{16}$, always on the same way of the Russian Penal Code of the years 1922-1926, as well as of the draft of the Code of Ukraine, making full its basic principles of Soviet legislation, perfectly compatible for this period with the policy conducted in Albania.

With regard to the phenomenon of corruption, it should be noted that with the establishment of communist system in Albania which applied the anti-bourgeois reforms, the new Albanian government declared the fight towards the corruption phenomenon having as purposes: the configuration of a new image for the State different from the previous State in the service of the bourgeoisie; the establishment of the state monopoly on incomes of officials and State administration limited strongly with the wage as the only source of living; the prohibition to take in the new administration people who do not make available to the Party - State their services; the reduction and, gradually, elimination of private property.

As can be seen, with the application of these anti corruptive policies, the new Albanian State was configured as a repressive State founded to disciplinary, administrative and, in particularly, to the penal measurements, actions addressed also towards the elimination of the last traces of corruption identified in the customs administration which the punishment was realized with kinds severity of measurements such as capital punishment. This strategy produced the punishment of the officials with penal acts with subject "attitudes on duty" or "incompetence", acts which in most cases have held political nature in the context of the sabotage of the political system. In the Penal Code of the year 1952, changed in the years 1958 and 1959, the punishment of the corruptive acts was sanctioned in the following articles: article 204, first paragraph, establishes the punishment up to 5 years with imprisonment of the official person that taking bribe for an act that is related to his duty.

As can be seen, the qualification of penal act of corruption it is related with the follows element: 1. the identification of the realization in the form of reward in money or with any other material reward, the fulfilment or not, as well as the performance or not of the act, of the moment of giving the bribe after performing or not performing, it is a moment that misses in the formulations of passive and active corruption in the Penal Code of the period in study ${ }^{17}$; 2 . the irrelevance of the promise or commitment of illegal actions as decided the Plenum of High Court with its decision of the date 30.07.1975 which clarifies that the moment of giving bribe even without promise or commitment of illegal acts, is a moment that misses in the formulations of passive and active corruption in the Penal Code; article 204, second paragraph, establishes that in the case the bribe is committed with pressure, more than one time or from a person who has the duty of a special importance, this person is condemned up to 10 years with imprisonment; article 205 declares the punishment up to 3 year with imprisonment of a person who giving bribe in the form of promise, as well as giving or intermediating for giving bribe, both in the case of the performance or not and in that after he has performed or not, except the case when is taken with pressure and that when has willingly denounced the act before the penal proceeding starts.

The last phase of the development of criminal law in Albania started after the constitutional reform of 1976. The penal code of 1977, entered into force on 1 October 1977 and approved by Law of 15 June 1977 no. 5591818, by legal and political point of view, was the apex of the communist dictatorship. It reflects the choices heavily politicized already anticipated in the text of the new Constitution of 1976. The Penal Code of 1977, modified in the 1981, has unified the bribe in one article: the article 109 which the content reports that of the articles 204 and 205 of the previous Penal Code highlighting the punishment up to 10 year imprisonment in the case described at the first paragraph of the article 204 and

citizen. The social and economic order founds at the forms of the state, co-operative and limited private properties. The constitutional organisation is based on the principle of the unity power of the State that the origin becomes by the concept of the people worker (Tahiraj R., Bridging the Sea. Constitutional and supranational limitations to taxing powers of the States across the Mediterranean Sea, Roma 2010).

${ }^{15}$ On special: suppression of sabotage of the power of the people punishing those that facilitated in any form war criminals; suppression of the theft of the assets of State; organization and operation of military courts; organization provisional criminal proceedings; suppression of the gold trade; reform agriculture; amnesty for illegal ordinary made until the liberation of Albania; confiscation of the property of enemies of the people; repression of criminal against the people and the state; suppression of illicit trade and that of the speculation and economic sabotage.

${ }^{16}$ The Penal Code of 1 September 1952 it is published in the Fletore Zyrtare, 1.08.1952, no. 15.

17 Decision of High Court, 6.11.1961, no. 237.

18 Fletore Zyrtare n. 3/1977, pg. 27-96. 
the punishment up to 3 year imprisonment or with the reeducation through hard work in the case described at the second paragraph of the article 204. At last, it should be noted the absence of the definition for the elements of figure of penal act letting space to the practice to make interpretations and definitions.

This situation remains unchanged until the beginning of the year 1991 noted as the Age of the Revolution which accelerates the process of the reforms ${ }^{19}$. With this change which produced the changes of political, economic, legal and social systems, the corruption become active because of some objective and subjective factors and, concretely: 1 . the cultivation of material resources through corruption by the employees of old administration who naturally felt that the day of their dismissal was not far away, as well as the new employees of administration as result of difficult economic situation and uncertainty in prospect at that position; 2. the numerous legal deficiencies in

the areas of new economic and financial life, previously unknown, situation thus dealt with deficient structures and the absence of the state control; the circulation of money in cash form which hinders the process of detection and evidencing of penal act.

In this situation resulted necessary to intervene in way to eliminate the corruption in the public administration. As result, have been implemented the first measures for the reform of the state administration, as well as the legal regulation of all sectors of life, especially, those related with the ownership of property and legal evidences of properties, with the legal activity of the structure of public administration, particularly, for conflicts of interests, publication of legislation and unification of official documentations, specially in the financial field, with the encouragement of the private banking system. Also, it was established and modernized the link controls of the State through the passage from the independent control of the executive power, High State Control Audit and till to links of internal control in the financial field or services of internal control for violation of law within the institutions, specially, to the customs and taxation.

These new developments have produced the improvement of the penal dispositions in relation to the corruption. A series of articles were added for acts that indirectly cultivate or hide the corruption or the corruptive activity in new fields, as well as the activities which are considered inadmissible in a democratic state as the political corruption for which the legislator has decided the punishment with imprisonment not less than 10 years or with death (this last abrogated) in the case that take or accept to receive for themselves or for other persons the reward in money or other things for performing actions in contradiction with the national interests. In fact, these measures are issued in the emergency of anti-corruption fight and were not associated with administrative and legal measures.

In the context of European integration, the fight against corruption became institutional after the year 1998 with the initiatives and plans of anti-corruption strategy undertaken by the government. This strategy followed in the years 2001, 2003 and 2007 with the changes of Penal Code to its approximation with the European Union law, recently materialized with the project of changes in the Penal Code approved in the year 2011.

In particular, in the framework of Stabilization and Association Agreement, the Albanian government approved a national plan which proposed concrete measures related to the fight against corruption and, concretely: 1 . the strengthen of the rule of law; 2. the protection of the independence and effectiveness of functioning of judicial system; 3 . the development the appropriate trainings; 4. the fight against the corruption and organized crime; 4. the cooperation of Albanian State with the European Union to prevent the criminal activities and illegal activities as the smuggling and trafficking of human beings, the illegal economic activity, corruption, illegal drug trafficking, falsification of documents and trafficking of cars.

The Penal Code actually in force detects the presence of three groups of provisions in relation to the corruption. The first group of provisions punishes the corruption with this definition and, concretely: the articles 244 and 245 for the active corruption; the articles 259 and 260 for passive corruption committed by people who perform public functions; the articles 164/a and 164/b for active and passive corruption in private sector; the articles 312, 319, 319/a related to the active and passive corruption in the field of justice. The second group of provisions punish the corruption, but not with that denomination: the article 124 which refers to the request for taking reward for Adoptions; the article 217 which describes the taking of rewards for actions in favour of a foreign power, against the independence and integrity; the article $245 / 1$ which refers the illegal influence towards public officials"; the article 253 related to the violation of equality of citizens; the article 257 which refers the illegal profit of interests; the article 328 relevant to the giving of rewards, promises in electoral

\footnotetext{
${ }^{19}$ In this context, the Popular Assembly approves a series of laws as the modification of the Labour Code, the protection of the foreign investments, the constitution of joint venture societies, the acknowledgment of the right to manifest in the public places and the introduction of the political pluralism. With the abolition of the Constitution of 1976 and with the promulgation of the Law for the Principal Constitutional Dispositions begins a new process noted as the process of the establishment of the new legal and institutional order. As result, Albania is a Democratic Republic founded to the legality principle, to the political pluralism and to the social solidarity. The constitution of the new juridical system sanctions the institution of the Constitutional Court (TAHIRAJ R., op. cit., Roma 2010).
} 
campaigns. The third group of provisions punishes the corrupting benefit as qualifying element of other acts as the articles 110/a, 114/a, 114/b, 128/b. The fourth group of provisions punishes the acts that in form have no relation with corruption, but generally are committed for that purpose: the articles 165, 168, and 170/a related to the falsification documentation, false information, illegal employment in commercial entities; the articles 175 and 181/a related to the smuggling in cooperation of the employees of customs or non-fulfilment of duties by employees of taxes; the articles 189/3 and 190/3 related to the falsification of identification cards, seals; the article 248 and 251 related to the actions and inactions in the measure of duty; the article 258 referred to the violation of parity in auctions and tenders; the article $313 / \mathrm{b}$, related to the revelation of information in violation of law; the article 324 which providing help to prisoners for leaving; the articles $325,326,327,331$, related to the electoral right.

However, it should be emphasized that the current penal provisions related to the corruption leaves much to be desired, as in regard of detection and scarce punishments, the differentiation of corruption by the acts in duty tented to be covered and also as regard of the kind of the measures of punishment, while the data of financial control institutions and of control according to the law of the investigation of judgment draw the attention for worrying situation. Also, the tendencies of the accomplishment of organized crime and that of internationalization of the new types of crimes in the banking field, as well as in the means of communication and of the new technologies for concealment of the incomes and properties, and at last the growth of bank turnover within and outside the country are circumstances that require a full modernization review of techniques and tactics of investigation and trial in Albania.

\section{The Implementation of Stability Pact Anti-Corruption Initiative in the SEE Countries}

The corruption in the countries of SEE have caused serious damages breaking the rule of law and the stability of democratic institutions, infringed the fundamental rights and freedoms, as well as undermining the trust and confidence of citizens in the fairness and impartiality of public administration. Moreover, the corruption has undermined the business climate, discouraged domestic and foreign investment, wasted economic resources and hampered economic growth, thus threatening the very objectives of peace, democracy and prosperity in SEE.

The mobilization of the countries of SEE to fight the corruption in the international context moved to the top of the regional political agenda, it is result of the necessity to afford the social, political and economic costs that bribery and corruption entail. For a long time, the bribing public officials to obtain any deal were at least a tolerated practice in the wide parts of the region. Today, the countries of the SEE, in collaboration with the international community, are playing by stricter rules.

The legal and institutional frameworks are being reformed according to the European and other international standards in order to promote a whole arsenal of legal instruments and to improve ethical standards in the public sector, to establish the rule of law, to curtail money laundering and to clean up public procurement practices. A crucial role, in order to turning these new rules into reality, is playing both the private sector and the civil society.

In response to this mobilization, the Stability Pact for SEE made the fight against corruption a top priority upon its founding in Cologne/Germany in June 1999 which was formally endorsed in Sarajevo a month later. On 16th February 2000, again in Sarajevo, the countries of SEE, with the presence of the European Union Member States and the assistance of the international community, transformed the Stability Pact for SEE in the Stability Pact of Anti-Corruption Initiative.

Following a multidisciplinary approach, the Stability Pact of Anti-Corruption Initiative provides incentives for policy reform and sets out a number of commitments for policy reforms that SEE countries need to implement in order to eradicate corruption and, concretely: 1. the adhesion to and implementation of universal and other European legal anticorruption instruments as well as implementation of multilateral/regional agreements; the promotion of good governance and reliable public administrations; the strengthening of legislation and promotion of the rule of law; the promotion of transparency and integrity in business operations; the promotion of an active civil society and raising public awareness.

With the implementation of the Stability Pact of Anti-Corruption Initiative, the environment for cooperation against corruption in SEE has changed considerably significant progress in the adoption of relevant international instruments and European Union Stabilization and Association Process. In line with the transformation of the Stability Pact into Regional cooperation Council and through a decision of the SEE countries, the Stability Pact of Anti-Corruption Initiative has been renamed in October 2007 to the Regional Anticorruption Initiative.

\subsection{The implementation of the Stability Pact of Anti-Corruption Initiative in Albania.}

Some progress was made regarding the government's policies to fight corruption in Albania. In relation to the strategic 
policy approach on corruption, a new anti-corruption action plan for the period 2011-2013 encompassing individual action plans for all government, ministries/agencies concerned was adopted in June 2011. The quality of action plans, including indicators to monitor progress, has improved. Implementation of action plans is proceeding. There has been progress in strengthening the legal framework by implementing recommendations of the Group of States against corruption related to the issue of incrimination and political party financing. Regarding incrimination, recommendations were partly implemented; the Criminal Code amendments are awaiting adoption in Parliament by a three-fifths majority vote. Regarding political party financing, all recommendations but one were implemented; the latter is partly implemented because there is no clear deadline for submitting party annual financial reports.

The institutional framework to combat corruption has been further developed. With a view to improving coordination in the implementation of the anti-corruption strategy, a clearer distribution of responsibilities was defined between the inter-ministerial working group, the inter ministerial Technical Group and the Technical Secretariat of the inter-ministerial working group. A new internal control department was established in the General Directorate of Customs. However, as in the Directorate of Tax Office, this department focuses more on financial control tasks than explicitly on anti-corruption measures. Free phone numbers for citizens to report suspected cases have been installed in a number of institutions concerned. Efforts to improve inter-institutional cooperation were made through the signing of memorandum of understanding foreseeing in particular an increased exchange of information and cooperation on investigations. The Department of Internal Control and Anti-Corruption and the High Inspectorate for Declaration and Audit of Assets have each signed separate such memoranda with the High Council of Justice and with an anti-corruption NGO. However, the implementation and effectiveness still have to be verified in practice.

Some limited preventive measures were taken by launching awareness-raising initiatives. However, overall implementation of anti-corruption measures remains insufficient. Corruption is prevalent in many areas and remains a particularly serious problem. There are shortcomings in the administrative capacity of relevant institutions and in the proposed mechanisms to ensure proper monitoring of the implementation of the anticorruption action plans. The DIACA in particular has not been strengthened sufficiently as regards its staff and its monitoring competences; its ability to effectively coordinate anticorruption policies accordingly remains limited. Reporting on anticorruption measures and implementation by responsible authorities, needs to be improved. Criminal law statistics as well as statistics on conflict of interest cases and prevention measures remain insufficient or unreliable.

There continues to be a lack of human resources and technical infrastructure in a number of investigation and law enforcement agencies. Joint Investigative Units, although continuing to be good instruments for investigating and prosecuting corruption cases, have insufficient human resources and technical equipment. HIDAA, although an important player in combating corruption, has limited resources to undertake extensive inspections and full audits of asset declarations by officials. In the light of this, HIDAA needs to further strengthen cooperation and exchange of information with other services such as the Financial Investigation Unit, Customs services, or the Immovable Property Registration in order to be able to conduct administrative investigations more effectively.

Investigation into possible corruption cases is hampered by the lack of access to the various registries (e.g. car registry and land register) by investigation and law enforcement agencies and by the lack of a central register of bank accounts. Proactive investigation, i.e. systematic, targeted and risk-based investigations into possible corruption areas and cases, is lacking in Albania. The full immunity of high level officials remains a major obstacle to effective and successful investigation. Immunity of judges is only rarely lifted and the lack of confidentiality in a case following the lifting of immunity seriously impedes effective investigation. Following an initiative by a number of Members of Parliament in the ruling majority MPs can waive their immunity in cases of criminal prosecution on corruption charges by signing an individual voluntary declaration at the start of their mandate; this followed the amendment of parliamentary rules and regulations on immunity from criminal prosecution. While this expresses political will to tackle high-level corruption, the legal validity of these declarations is open to question. An amendment of the relevant constitutional provisions may be required in order to limit or abolish immunity both for judges and for MPs. Although cooperation between agencies, including joint training, has improved further, the exchange of relevant information is often late or ineffective. Cooperation between law agencies and prosecution on the one hand, and courts on the other, remains insufficient.

Little progress has been made in developing a solid track record of proactive investigations, prosecutions and convictions in corruption cases at all levels, which is a key priority of the Opinion. In particular, investigation of medium and high level corruption cases is rare. The General Prosecutor launched an investigation on charges of corruption and misuse of office against the former Deputy Prime Minister (PM), llir Meta, following the publication of a controversial video. This subsequently also led to charges being brought against the former Minister of Economy, Dritan Prifti. The case concerning former deputy PM Meta, the only high-level case which has gone to the High Court, it is concluded in 16.02.2012 in favour of the former deputy PM llir Meta who is declared innocent for the offence of active corruption of 
higher State or local elected officials under article 245 of the Penal Code, after the fact does not prove that there is, according to the article 388, paragraph 1, letter "a" of the Code of Criminal Procedure ${ }^{20}$. Overall, limited progress was made in the field of anti-corruption policy, which is a key priority of the Opinion. Although the legal framework and interagency structures are mostly in place, implementation of specific actions on the other hand remains ineffective overall and the results are insufficient. Public awareness campaigns are only just starting. The immunity of certain public officials, the absence of a proactive approach and the lack of resources and equipment continue to seriously obstruct effective investigation. There is no solid track record of investigations, prosecution and convictions at all levels. Corruption is prevalent in many areas and continues to be a particularly serious problem.

Regarding the independence of the judiciary, no progress was made. The independence of the High Court needs to be guaranteed, including through a revision of the current system of appointments in order to avoid politicization. The neutrality and independence of the Constitutional Court needs to be guaranteed, including through a proper process for the appointment and hearing of judges in Parliament, free from political influences. In relation to accountability in the judiciary, the full immunity enjoyed by judges remains one of the main factors obstructing investigation into possible cases of corruption in the judiciary. Widespread corruption is a key factor hampering the accountability of the judiciary. The Ministry of Justice (MJ) and the High Council of Justice ( $\mathrm{HCJ}$ ) have adopted a Memorandum of Understanding to address the overlap of inspection competences between the inspectorates of the two institutions, as a transitory measure before a new HCJ law is adopted.

Regarding the efficiency of the judiciary, some limited progress was made. The $\mathrm{HCJ}$ introduced changes to the system of evaluating judges and made improvements in the reasoning of appointment decisions; in addition, the Commission on transfers, promotion and appointments of judges was created. However, the effectiveness of the new evaluation system needs to be verified in practice. Reforms of the law on the High Court aimed at improving efficiency are delayed. Working conditions in courts are generally still poor and hearings often take place in judges' offices, which hampers transparency and efficiency. The yearly budget for the judiciary remains insufficient.

Court management remains poor due to a lack of human and financial resources, in particular in first instance district courts. The backlog of court cases is still problematic. Unreasonable delays in court cases due to postponement of court proceedings because of the absence of lawyers or judges remain a matter of serious concern. A computerized case management and random allocation of cases in criminal and civil procedures are in place in most - but not all - judicial offices ${ }^{21}$

\subsection{The implementation of the Stability Pact of Anti-Corruption Initiative in Macedonia}

Further amendments to the legal framework, which are a key priority of the accession partnership, were made in Macedonia. Legislative amendments were adopted with a view to implementing GRECO's third round recommendations concerning incrimination and transparency of party funding. The amended Criminal Code refines the scope of incrimination for bribery and trading in influence and introduces criminal liability for failure to report funds used to finance electoral campaigns. The amended Electoral Code introduced a requirement to submit financial reports for all election campaigns to the relevant authorities. The new Criminal Procedure Code, which becomes applicable in November 2012, strengthens the role of the public prosecutor in the pre-trial procedure and introduces a number of special investigative measures. However, the Law on financing of political parties still remains to be amended.

In 2010, the Sector for Internal Control and Professional standards within the Ministry of Interior brought criminal charges against 29 police officers for criminal offences, including 16 cases of alleged abuse of an official position. Five police officers from one border crossing point were charged as part of a single operation. On the whole the number of instances of corruption among the border police has been decreasing as a result of anti-corruption programs, anticorruption training, CCTV monitoring and salary increases. The Customs Administration should be prioritized as a high corruption risk in the development and implementation of future anti-corruption programs. The case of high level corruption concerning the former Director of the Public Revenue Office was completed when the conviction was confirmed by the Supreme Court. The four other high-level corruption cases in which the defendants (including a former prime minister, a former minister of defence and a former governor of the National Bank) had previously been sentenced to imprisonment, were quashed on appeal and returned to the first instance courts for retrial, due to insufficient examination of the facts. The capacity of the judiciary to deal with sensitive high level corruption cases remains weak.

\footnotetext{
${ }^{20}$ For more see: (Decision of High Court of 16.02.2012, no. 8, http://www.gjykataelarte.gov.al/).

${ }^{21}$ Commission Staff Working Paper Albania 2011 Progress Report, Communication From The Commission To The European Parliament And The Council, Enlargement Strategy and Main Challenges 2011-2012, Brussels, 12.10.2011, SEC (2011) 1205 final.
} 
The lack of systematic content checks on asset declarations and conflict of interest statements hampers the effectiveness of the reporting obligation in deterring corruptive practices in the public administration. The SCPC, in cooperation with a number of other institutions, has introduced a methodology for carrying out verifications of asset declarations; the process needs to be taken forward. Legislative changes are still necessary before systematic content checks can be carried out on conflict of interest statements. Conflicts of interest are not sanctioned in practice.

The legal framework and the measures taken as regards the financing of political parties are deficient. The governing coalition parties spent more on election financing in 2011 than their declared income. Questions have also been raised about the legality of SDSM's campaign financing. However the institutional structure for addressing campaign financing and the sanctioning system remain unclear.

Transparency of public expenditure remains unsatisfactory. The SCPC recommended pressing criminal charges for the misuse of public funds, but none of the cases forwarded in 2009 and 2010 to the Public Prosecutor's Office have been resolved. Existing legislation on public access to information has yet to be amended in order to ensure full transparency. The internal control mechanisms in public administration remain critically weak. Legal and institutional protection of whistle blowers continues to be problematic and insufficient, discouraging reporting of suspicious cases.

The competent bodies tasked with combating corruption continue to lack a pro-active approach and failed to dispel widespread allegations of corruption in key areas of concern, such as public procurement and financing of political parties. A convincing track record has yet to be established for prosecutions and convictions. The new Criminal Code provisions on extended confiscation, illicit enrichment and criminal liability of legal persons have yet to be implemented.

The State Commission for the Prevention of Corruption (SCPC), the Anti-corruption Unit within the Organized Crime Department of the Ministry of Interior and the Basic Public Prosecutor's Office for the Fight against Organized Crime and Corruption all remain understaffed and underfinanced. The specialization of law enforcement agents and the judiciary at local level, particularly in the area of petty corruption, remains insufficient.

The Law on prevention of corruption was amended to confer professional status on the SCPC; however, public confidence in its independence remains fragile. Questions have been raised about the criteria used by parliament in the selection of the seven new members of the SCPC in April. The SCPC itself concluded in its 2010 annual report that the significant cut in its budget and mandate called into question the political will to combat corruption effectively.

Cooperation between the Ministry of Justice, SCPC and law enforcement agencies needs to be strengthened. Meaningful analysis of the level and type of corruption in various areas has yet to be carried out. Collection and processing of relevant data for measuring the extent and nature of corruption, as well as the effectiveness of anticorruption measures, remain deficient. Corruption remains a serious concern.

Overall, further amendments were made to the legal framework for anti-corruption policy, which is a key priority of the accession partnership. GRECO recommendations were addressed and the legal framework is well advanced. Limited progress was made in implementation. A track record in handling high level corruption cases has yet to be established. The verification of declarations of assets and conflicts of interest needs to be systematized and institutionalized. Transparency of public expenditure and of the funding of political parties remains insufficient. More pro-active interinstitutional cooperation is necessary. Corruption remains prevalent in many areas and continues to be a serious problem ${ }^{22}$.

\subsection{The implementation of the Stability Pact of Anti-Corruption Initiative in Croatia}

Good progress can be reported in the prevention of corruption in Croatia. Croatia has taken a number of measures to strengthen the legal and institutional framework. Measures are being implemented in accordance with Croatia's anticorruption action plan. Croatia has increased transparency and integrity in its public administration and state owned companies. Amendments to the law on access to information were adopted, which introduce clearer procedures and deadlines for information requests and supervision of the implementation of the law by the Data Protection Agency. Croatia adopted a new law on the financing of political activities and election campaigns, which improves transparency and independent oversight and increases the penalties for non compliance with the law. Changes to the Conflict of Interest Act provide for the depolarisation of appointments to supervisory boards of state owned companies, as well as of the membership of the conflict of interest commission itself. Sanctions in cases of conflict of interest have also been

\footnotetext{
${ }^{22}$ Commission Staff Working Paper The Former Yougoslav Republic Of Macedonia 2011 Progress Report, Communication From The Commission To The European Parliament And The Council, Enlargement Strategy and Main Challenges 2011-2012, Brussels, 12.10.2011, SEC (2011) 1203 final.
} 
strengthened. Measures were taken to raise awareness of potential conflicts of interest, in particular at the local level. Amendments to the Labour Act have enhanced protection for whistleblowers.

\section{Conclusions}

The Stability Pact Anti-Corruption Initiative was born out of the conviction that corruption is a serious threat to the development and stability of SEE countries. Albania, Macedonia and Croatia are committed to the Stability Pact AntiCorruption Initiative Compact and Action Plan and are actively implementing new measures to fight the corruption where significant efforts have been made to accede to key international legal instruments containing anti-corruption related provisions. Nevertheless, further actions are needed, in particular, with regard to effective implementation of these instruments and the implementation of further steps.

In the most of the countries of SEE, measures have been undertaken or are under consideration to strengthen legislation related to international co-operation and mutual legal assistance in criminal matters. However, deficiencies, to a greater or lesser degree, are apparent in all countries. Additional efforts are required to make co-operation mechanisms more effective by further promoting direct contacts with judicial, prosecutorial and law enforcement institutions abroad and in the region, by establishing a network of contacts and by appointing and training officials who would be responsible for international co-operation with and in relevant institutions.

Particular efforts are also required in the field of data protection. The existence of European data protection standards is usually a pre-condition for the exchange of sensitive data among European countries. In this regard, efforts are required in Croatia where related legislation still needs to be adopted and implemented.

\section{References}

Adamiti, Le Pélasges et leurs descendants les Albanais, Caire 1903.

Stipcevic A., Çdo tregim për Ballkanin fillon me llirët, Prishtinë 1985.

Cuaz M., II tema dell'identità nazionale nella storiografia albanese, Passato e Presente, Vol. 14/39, Firenze 1996.

A.A. V.V., Historia e Shtetit dhe e së Drejtës në Shqipëri, Vol. 1, Tirana 2000.

Swander-Sievers S. \& Fisher B. J., Albanian identities: myth and history, Bloomington 2002.

Castellan G., Histoire de l'Albanie et des albanais, Lecce 2004.

Hasluck M., The unwritten law in Albania, Cambridge 1954.

Gjeçov P. S. C.,, Codice di Lek Dukagjini, Reale Accademia d'Italia - XX, Roma 1941.

Resta P., Il Kanun di Lek Dukagjini. Le basi giuridiche e morali della società albanese, Nardò 2000.

Mommsen T., Römische Geschichte, trad. it., Storia di Roma antica, III, Firenze 1972.

Tachella P., Temi e questioni di storia economica dell'Albania dalla dominazione ottomana al crollo del comunismo. Una rassegna bibliografica, Storia Economica 9/1, Napoli 2006.

Corpus Statutario delle Venezie - Statuti di Scutari - della prima metà del secolo XV con le addizioni fino al 1469, Roma 2002.

Tahiraj R. \& Porro S., Il sistema tributario in Albania. Evoluzione storica dal 1839 al 1945, Italy 2008.

Losano M. G., L'ammodernamento giuridico della Turchia (1839 - 1926), Milano 1990.

Law Decree of 22 July 1924, For the proposal of Ministry of Finances that decree the forming of Commission for simplifying of bureaucracy and reduction of employers.

Tomes J., The Throne of Zog, History Today, Tirana 2001.

Tomes J. King Zog of Albania: Europe's self made Muslim monarch, New York 2004.

Ismet E., Zhvillimi historik i legjislacionit penal në Shqipëri, Tirana 1997.

Salvatorelli L. -Mila G., Storia d'Italia nel periodo fascista, Torino, 1964.

Ballvora SH., Vendosja e rregjimit kolonial fashist të pushtimit në Shqipëri, Studime Historike N. 3, Tirana 1967

Felice DE R., Mussolini il Duce. Lo Stato totalitario 1936-1940, Torino, 1981.

Fischer B., Albania at the war, 1939-1945, London 1999; CIANO G., Ditari i Kontit Ciano: Shqipëria (1937-1943), Tirana 1994.

Tahiraj R., Bridging the Sea. Constitutional and supranational limitations to taxing powers of the States across the Mediterranean Sea, Roma 2010.

Fletore Zyrtare, 1.08.1952, no. 15.

Decision of High Court, 6.11.1961, no. 237.

Fletore Zyrtare n. 3/1977.

Decision of High Court of 16.02.2012, no. 8, http://www.gjykataelarte.gov.al.

Commission Staff Working Paper Albania 2011 Progress Report, Communication From The Commission To The European Parliament And The Council, Enlargement Strategy and Main Challenges 2011-2012, Brussels, 12.10.2011, SEC (2011) 1205 final.

Commission Staff Working Paper The Former Yougoslav Republic Of Macedonia 2011 Progress Report, Communication From The Commission To The European Parliament And The Council, Enlargement Strategy and Main Challenges 2011-2012, Brussels, 12.10.2011, SEC (2011) 1203 final. 
Commission Staff Working Paper Bosnia And Hercegovina 2011 Progress Report, Communication From The Commission To The European Parliament And The Council, Enlargement Strategy and Main Challenges 2011-2012, Brussels, 12.10.2011, SEC (2011) 1206 Final.

Commission Staff Working Paper Bosnia And Hercegovina 2011 Progress Report, Communication From The Commission To The European Parliament And The Council, Enlargement Strategy and Main Challenges 2011-2012, Brussels, 12.10.2011, SEC (2011) 1200 final. 